\title{
KEMAMPUAN PENALARAN MATEMATIS SISWA LAKI-LAKI DAN PEREMPUAN DALAM MENYELESAIKAN SOAL PISA KONTEN CHANGE AND RELATIONSHIPS
}

\author{
Heddidayani Manalu ${ }^{1}$, Risma Simamora ${ }^{2}$, Akhmad Faisal Hidayat ${ }^{3}$ \\ Mahasiswa Pendidikan Matematika, FKIP, Universitas Batanghari, Jambi ${ }^{1}$ \\ Dosen Pendidikan Matematika, FKIP Universitas Batanghari, Jambi ${ }^{2,3}$ \\ Email: heddidayani6@gmail.com
}

\begin{abstract}
ABSTRAK
Penelitian ini bertujuan untuk mengetahui bagaimana kemampuan penalaran matematis siswa laki-laki dan perempuan dalam mengerjakan soal PISA berdasarkan indikator kemampuan penalaran. dalam penelitian ini populasi yang peneliti ambil adalah seluruh siswa kelas XI MIPA 3 SMA $N 3$ Kota Jambi. hasil penelitian yang diproleh nilai rata-rata laki-laki 66,85 sedangkan rata-rata siswa perempuan 70,18. berdasarkan indikator kemampuan penalaran matematis yang pertama, siswa laki-laki masih melakukan kesalahan dalam menuliskannya sedangkan siswa perempuan dalam mengajukan dan menuliskan dugaan sudah lengkap.Berdasarkan indikator kedua, siswa laki-laki dapat menentukan pola, sedangkan pada siswa perempuan cenderung banyak melakukan kesalahan dalam menentukan dan membuat pola.Berdasarkan indikator ketiga,dalam membuat manipulasi matematika siswa laki-laki melakukannya dengan langkahlangkah singkat,sedangkan siswa perempuan melakukannya dengan lengkap dan disertai satuan untuk setiap penulisannya.sedangkan untuk indikator keempat yaitu menarik kesimpulan, laki-laki dan perempuan tidak dapat melakukannya.
\end{abstract}

Kata kunci:

Kemampuan Penalaran Matemati; PISA.

\begin{abstract}
This study aims to find out how mathematical reasoning abilities of male and female students in working on PISA problems based on indicators of reasoning ability. in this study the population the researchers took were all students of class XI MIPA 3 SMA N 3 Kota Jambi. the results of the study obtained an average value of 66.85 male men while the average female student was 70.18. based on the first mathematical reasoning ability indicator, male students still make mistakes in writing it while female students in submitting and writing allegations are complete. Based on the second indicator, male students can determine patterns, whereas female students tend to make many mistakes in determining and make a pattern. Based on the third indicator, in making mathematical manipulation male students do it with short steps, while female students do it completely and accompanied by units for each writing. While for the fourth indicator that is drawing conclusions, men and women do not can do it.
\end{abstract}

Keywords :

Mathematical Reasoning Ability; PISA.

\section{PENDAHULUAN}

Matematika berperan sebagai sarana untuk melatih cara berpikir dan bernalar dalam menarik kesimpulan serta mengembangkan kemampuan memecahkan masalah, baik masalah dalam matematika itu sendiri, bidang lain, maupun masalah dalam kehidupan seharihari. Sesuai dengan tujuan pembelajaran matematika dan proses pendidikan matematika tampak bahwa penalaran merupakan kemampuan yang perlu dimiliki oleh siswa. Jadi, Kemampuan penalaran matematis adalah kemampuan menghubungkan permasalahanpermasalahan kedalam suatu ide atau gagasan sehingga dapat menyelesaikan permasalahan matematis. kemampuan 


\section{$\pi$ (Phi)}

penalaran matematis setiap anak pasti berbeda antar satu anak dengan anak lainnya.terutama antara siswa laki-laki dan perempuan. Rendahnya kemampuan penalaran siswa tidak terlepas dari proses pembelajarannya di sekolah. umumnya di sekolah siswa tidak terbiasa menyelesaikan soal dengan karakteristik konteks nyata, melainkan mengerjakan soal-soal yang dicontohkan oleh gurunya tanpa mereka mengetahui manfaatnya dalam kehidupan sehari-hari. Untuk mengetahui perbedaan kemampuan penalaran matematis antara siswa laki-laki dan perempuan, diperlukan soal yang kemampuan penalaran matematis yang cukup tinggi dalam menyelesaikannya soal PISA salah satunya. PISA (Programme for Internasional Student Assessment) merupakan suatu penilaian secara internasional terhadap keterampilan dan kemampuan siswa usia 15 tahun, yang diselenggarakan oleh Organization for Economic Cooperation and Development (OECD). Tujuan umum dari studi PISA adalah untuk menilai sejauh mana kemampuan siswa usia 15 tahun di Negara OECD dan Negara lainnya sudah memperoleh kemahiran yang tepat dalam membaca, matematika dan sains (OECD, 2009). Secara umum faktor penyebab kesalahan adalah kemampuan penalaran dan kreativitas siswa yang rendah dalam memecahkan masalah konteks nyata dan memanipulasinya kedalam bentuk aljabar. Karena itu dilakukan penelitian dengan judul Kemampuan Penalaran Matematis Siswa Laki-Laki Dan Perempuan Dalam Menyelesaikan Soal Pisa Konten Change And Relationships.

Adapun tujuan dari penelitian ini untuk mendeskripsikan kemampuan penalaran matematis siswa laki-laki dan perempuan dalam menyelesaikan soal PISA konten change and relationships.

\section{METODE PENELITIAN}

Sesuai dengan permasalahan yang telah dikemukakan sebelumnya maka jenis penelitian yang digunakan dalam penelitian ini adalah penelitian komparatif dengan analisis deskriptif, ini nantinya untuk mengetahui perbedaan kemampuan penalaran matematis laki-laki dan perempuan. kemudian dideskripsikan untuk menganalisis dan menghasilkan gambaran tentang kemampuan penalaran matematis siswa laki-laki dan perempuan dalam menyelesaikan soal PISA konten change and relationships.

Populasi dalam penelitian ini adalah siswa kelas XI MIPA 3 di SMA Negeri 3 Kota Jambi. Penentuan Sampel pada penelitian ini menggunakan teknik Sampel Jenuh. Sampel Jenuh adalah teknik penentuan sampel bila semua anggota populasi digunakan sebagai sampel. Sehingga sampel dalam penelitian ini adalah seluruh siswa kelas XI MIPA 3 di SMA Negeri 3 Kota Jambi. Instrumen dalam penelitian ini adalah lembar tes soal PISA. Teknik analisis yang digunakan ialah statistik deskriptif, kemudian disajikan dengan diagram lingkaran dan diagram batang. Setelah itu melakukan perhitungan dengan mencari nilai mean, median, modus, dan standar deviasi.

\section{HASIL DAN PEMBAHASAN}

Data hasil tes tertulis pada penelitian ini diambil dari 29 siswa dengan 7 siswa laki-laki dan 22 siswa perempuan. Tes ini berupa instrumen penilaian tes kemampuan penalaran matematis sebanyak 5 butir soal uraian yang berhubungan dengan konten change and relationships atau aljabar PISA. Hasil penelitian ini yaitu data yang diproleh dari hasil analisis jawaban siswa berdasarkan indikator kemampuan penalaran matematis serta dilihat dari acuan pedoman penskoran/ rubrik kemampuan penalaran matematis. Hasil penelitian kemampuan penalaran matematis laki-laki dan perempuan tersebut menggunakan mean, 


\section{$\pi$ (Phi)}

median, dan modus. Mean digunakan ketika data memiliki sebaran normal atau mendekati normal. Median adalah nilai yang berada ditengah-tengah data setelah diurutkan dari yang terkecil sampai terbesar. Median digunakan bila ada data yang kita miliki tidak menyebar normal atau memiliki nilai yang berbeda-beda secara signifikan. Modus adalah nilai yang paling banyak muncul dari data. Modus digunakan untuk mengetahui data kategorik (nominal atau ordinal).

\section{Deskripsi Kemampuan Penalaran Matematis Siswa Laki-Laki}

Berdasarkan dari hasil penelitian menunjukkan ada 1 orang siswa yang berkemampuan tinggi, 4 siswa laki-laki dengan berkemampuan sedang, dan 2 siswa laki-laki yang berkemampuan rendah, dimana nilai rata-rata dari laki-laki adalah 66,85. Sedangkan modus adalah 60 . Dimana modus disini menunjukkan nilai yang sering muncul yang dimiliki oleh siswa laki-laki dan Standar deviasinya 11.55. Berdasarkan hasil penelitian serta dari keempat indikator kemampuan penalaran matematis, dapat dideskripsikan bahwa siswa laki-laki dalam menuliskan apa yang diketahui dan ditanya dalam soal menuliskannya lengkap tetapi masih terdapat sedikit kesalahan terutama pada soal nomor tiga. serta dapat menentukan pola serta hubungan dalam menganalisis situasi matematika tetapi masih terdapat sedikit kesalahn terutama pada soal nomor dua siswa laki-laki tidak menuliskannya, sedangkan untuk memanipulasi matematikanya menuliskan pengerjaannya dengan langkah-langkah penyelesaiannya secara singkat dengan terdapat bagian yang benar, menuliskan hasil akhir benar tetapi tidak disertai satuan, dan tidak melakukan penarikan kesimpulan untuk setiap pengerjaan soal.

\section{Deskripsi Kemampuan Penalaran Matematis Siswa Perempuan}

Berdasarkan hasil penelitian menunjukkan ada 11 siswa perempuan yang berkemampuan tinggi, 10 siswa perempuan dengan berkemampuan sedang, dan 1 siswa yang berkemampuan rendah, dimana nilai rata-rata dari perempuan adalah 70,18. Sedangkan modusnya ialah 56. dimana modus disini menunjukkan nilai yang sering muncul yang dimiliki oleh siswa perempuan. dan Standar deviasinya $11,84$.

Pada indikator pertama siswa perempuan kecendrungan menuliskan apa yang diketahui dan ditanya secara lengkap walaupun masih terdapat sedikit kesalahan, sedangkan untuk indikator kedua yaitu menentukan pola serta hubungan dalam menganalisis situasi matematika masih banyak terdapat kesalahan yang dilakukannya, menuliskan pengerjaan soal dengan langkah-langkah penyelesaiannya lengkap dengan hasil akhirnya benar walaupun pada soal nomor dua masih banyak melakukan kesalahan, menuliskan hasil akhir benar dengan disertainya satuan, dan untuk penarikan kesimpulan siswa perempuan terdapat banyak kesalahan untuk setiap pengerjaannya.

\section{Perbandingan Kemampuan \\ Penalaran Matematis Siswa Laki- Laki dan Perempuan}

Berdasarkan hasil penelitian yang sudah dilakukan maka didapat $\bar{X}_{\text {Laki-Laki }}=66,85$ dan $\bar{X}_{\text {Perempuan }}=$ 70,18 . Dari hasil dapat dinyatakan siswa perempuan lebih unggul dilihat dari nilai rata-ratanya. siswa laki-laki dalam menuliskan apa yang diketahui dan ditanya dalam soal menuliskannya lengkap tetapi masih terdapat sedikit kesalahan terutama pada soal nomor tiga. serta dapat menentukan pola serta hubungan dalam menganalisis situasi matematika tetapi masih terdapat sedikit kesalahn terutama pada soal nomor dua siswa laki-laki tidak menuliskannya, sedangkan untuk 


\section{$\pi$ (Phi)}

memanipulasi matematikanya menuliskan pengerjaannya dengan langkah-langkah penyelesaiannya secara singkat dengan terdapat bagian yang benar, menuliskan hasil akhir benar tetapi tidak disertai satuan, dan tidak melakukan penarikan kesimpulan untuk setiap pengerjaan soal.

Pada indikator pertama siswa perempuan kecendrungan menuliskan apa yang diketahui dan ditanya secara lengkap walaupun masih terdapat sedikit kesalahan, sedangkan untuk indikator kedua yaitu menentukan pola serta hubungan dalam menganalisis situasi matematika masih banyak terdapat kesalahan yang dilakukannya, menuliskan pengerjaan soal dengan langkah-langkah penyelesaiannya lengkap dengan hasil akhirnya benar walaupun pada soal nomor dua masih banyak melakukan kesalahan, menuliskan hasil akhir benar dengan disertainya satuan, dan untuk penarikan kesimpulan siswa perempuan terdapat banyak kesalahan untuk setiap pengerjaannya.

\section{SIMPULAN DAN SARAN}

Berdasarkan hasil penelitian ini, dapat diproleh dengan nilai Hasil penelitian yang diproleh $\overline{\mathrm{X}}_{\text {laki-laki }}=$ 66,85 dan $\quad \bar{X}_{\text {perempuan }}=70,18$. Berdasarkan indikator kemampuan penalaran matematis yang pertama, siswa laki-laki masih melakukan kesalahan dalam menuliskannya sedangkan siswa perempuan dalam mengajukan dan menuliskan dugaan sudah lengkap. Berdasarkan indikator kedua, siswa lakilaki dapat menentukan pola, sedangkan pada siswa perempuan cenderung banyak melakukan kesalahan dalam menentukan dan membuat pola. Berdasarkan indikator ketiga, dalam membuat manipulasi matematika siswa laki-laki melakukannya dengan langkah-langkah singkat, sedangkan siswa perempuan melakukannya dengan lengkap dan disertai satuan untuk setiap penulisannya.
Sedangkan untuk indikator keempat yaitu menarik kesimpulan, laki-laki dan perempuan tidak dapat melakukannya.

Jadi dapat disimpulkan bahwa siswa laki-laki lebih unggul pada indikator kedua yaitu menentukan pola dan hubungan untuk menganalisis situasi matematika, sedangkan siswa perempuan lebih unggul pada indikator pertama yaitu mengajukan dugaan dan indikator ketiga yaitu membuat manipulasi matematika.

Bagi guru disarankan agar dapat menambah bahan ajar yang berbentuk soal bertipe PISA serta memperkenalkan soalsoal yang bertaraf internasional kepada siswa, kemudian dapat mengapresiasi dalam perbaikan evaluasi pembelajaran dan sebagai alternatif dalam memperkaya variasi pembelajaran sehingga dapat digunakan untuk melatih kemampuan pemahaman matematis siswa dan sebagai apresiasi dalam perbaikan evaluasi pembelajaran. Bagi siswa disarankan agar dapat membiasakan diri untuk berlatih mengerjakan soal PISA agar bisa menjadi bahan untuk mengikuti literasi PISA. Selain itu, disarankan dalam mengerjakan soal hendaknya ditulis dengan tahap-tahap yang jelas dan rinci serta menuliskan satuannya. Sedangkan bagi peneliti selanjutnya disarankan untuk melakukan kajian lebih mendalam mengenai kelebihan kemampuan penalaran matematis tiap gender, karena sampai saat ini masih sedikit informasi yang dapat diproleh untuk dijadikan sumber atau bahan pendukung dalam penelitian ini, sehingga sumber yang dapat dipakai untuk peneliti lanjutan lebih beragam.

\section{DAFTAR PUSTAKA}

Lestari dan Yudhanegara. (2017). Penelitian Pendidikan Matematika. Bandung: PT. Refika Aditama.

Nafi'an Muhammad. Prosiding: ISBN 978-979-16353-6-3. Kemampuan Siswa Dalam Menyelesaikan Soal 
Cerita Ditinjau Dari Gender Di Sekolah Dasar. Dipetik 10 Januari 2019.

OECD. (2009). PISA Take the test: Sample questions from OECD'S PISA Assessments. OECD

Aceng, R. (2011). Filsafat ilmu lanjutan. Jakarta: Kencana Prenada Media Group.

Rahmat, Saeful Pupu. (2018). Psikologi Pendidikan. Jakarta: Bumi Aksara.

Stacey, K. (2010). Mathematics teaching and learning to reach beyond the basics. Australia: Research

Conference University of Melbourne, Vol. 2 No. 2, diakses 14 februari 2019.

Sugiyono. (2015). Metode Penelitian

Pendidikan. Bandung: Alfabeta

Sukayasa, (2012). Karakteristik penalaran siswa SMP dalam memecahkan masalah geometri ditinjau dari perbedaan gender. Universitas Tadolako, Vol. 3 No. 1, diakses

Susilowati, J. P. A. Jurnal Review Pembelajaran Matematika: Profil Penalaran Siswa SMP dalam Pemecahan Masalah Matematika ditinjau dari Perbedaan Gender, Vol. 1 No. II, (http:// jrpm.uinsby.ac.id, diakses 18 November 2018).

Thobroni, M. (2016). Belajar dan Pembelajaran. Yogyakarta: ArRuzz Media. 